\author{
УДК 324(477) \\ https://doi.org/10.34142/24130060.2019.19.2.08
}

\title{
ЕВОЛЮЦІЯ ТА ТРАНСФОРМАЦІЯ ВИБОРЧИХ ПРОЦЕСІВ В УКРАЇНI
}

\author{
Г.М. Нечасва
}

Харківський національний педагогічний університет імені Г.С. Сковороди

Стаття присвячена аналізу еволючії та трансформації законодавчого забезпечення виборчого процесу в украӥнському суспільстві. Особливий акцент робиться на визначенні поняття «виборчого процесу», який розкриває перспективи змін моделей, динаміку розвитку всіх систем та підсистем, напрями вдосконалення механізмів та технологій функціонування різних політичних суб'єктів. Розглянуто становлення та реформування виборчого прочесу в Україні, який має суттєве значення для розвитку Украӥни як правової та демократичної держави.

Ключові слова: вибори, виборча система, виборчий прочес, виборчі практики, виборче законодавство.

\section{ЭВОЛЮЦИЯ И ТРАНСФОРМАЦИЯ ИЗБИРАТЕЛЬНЫХ ПРОЦЕССОВ В УКРАИН}

\section{А.Н. Нечаева}

Статья посвящена анализу эволющии и трансформаџии законодательного обеспечения избирательного процесса в украинском обществе. Особый акиент делается на определении понятия «избирательного процесса», который раскрывает перспективы изменений моделей, динамику развития всех систем и подсистем, направления совершенствования механизмов и технологий функиионирования различных политических субъектов. Рассмотрено становление и реформирование избирательного процесса в Украине, который имеет существенное значение для развития Украины как правового и демократического государства.

Ключевые слова: выборы, избирательная система, избирательный прочесс, избирательные практики, избирательное законодательство.

\section{EVOLUTION AND TRANSFORMATION OF ELECTORAL PROCESSES IN UKRAINE}

\section{A. Nechaeva}

The article is devoted to the analysis of the evolution and transformation of the legislative support of the electoral process in Ukraine. Particular emphasis is placed on defining the notion of "electoral process», which reveals the prospects of model changes, the dynamics of development of all systems and subsystems, directions of improvement of mechanisms and technologies of functioning of different political actors, tendencies of internal and external influences on the behavior of participants of this process and other factors, which make it possible to fully characterize the nature and features of democratic development. The views of scientists involved in the electoral process have been analyzed and the concept of the electoral 
process is formulated. The formation and reform of the electoral process in Ukraine, which is essential for the development of Ukraine as a rule of law and democracy, are considered. Elections are one of the most important institutions of democracy, a form of direct exercise of power by the people themselves. In Ukraine the basic principles for organizing and holding elections are defined at the constitutional level. It is noted that the election institute in Ukraine has passed a significant historical and difficult path for social development. During the years of independence in Ukraine, elections to the Verkhovna Rada were held in 1998, 2002, 2006, 2007, 2012, 2014, 2019. It is justified that during this time the legislation on elections, including types of electoral systems, has been repeatedly changed. There are many shortcomings and gaps in the electoral legislation so far, and the urgent need is to create an effective mechanism that would ensure timely self-renewal of the political system, taking into account the changing domestic and international conditions, and the principles of democracy and self-government in all spheres of life. The necessity of reforming the electoral legislation, which would not contradict international electoral standards, should be noted and further developed.

Keywords: elections, electoral system, electoral process, elective practices, electoral law.

Постановка проблеми. Вибори є однією 3 ключових форм прояву демократії у країні. Вони є найвищим реальним вираженням волі народу, конституційним способом формування органів державної влади та органів місцевого самоврядування на основі вільного волевиявлення громадян (Готун, 2008, с. 51). Особливого значення набуває виборчий процес, адже саме він розкриває перспективи змін моделей, динаміку розвитку всіх систем та підсистем, напрями вдосконалення механізмів та технологій функціонування різних політичних суб'єктів, тенденції внутрішніх та зовнішніх впливів на поведінку учасників цього процесу та інші чинники, які дозволяють всебічно характеризувати сутність та особливості демократичного розвитку, одним 3 каналів якого i виступають вибори (Кормич та Кормич, 2013, с. 28).

Постаючи у якості безперервного політико-правового процесу, становлення і реформування виборчої системи привертає до себе особливу увагу i фахівців-науковців, експертів, і виборців загалом. Науковцями відзначається як загалом суттєвий вплив виборчої системи на різні сфери життя суспільства, так і іiї важливість при формуванні стабільної партійної системи, парламенту, уряду, місцевих органів державної влади, а також іiі вплив на організацію виборчого процесу, поведінку політичних партій, членів представницьких органів та кандидатів на виборні посади (Наход, 2011 , с. 1). Таким чином, спираючись на грунтовну аргументацію та значний 
дослідницький матеріал провідних українських науковців щодо важливості виборів як фундаментальної складової процесу демократизації, вважаємо за необхідне проаналізувати еволюцію та трансформацію виборчих процесів в Україні, в ракурсі відповідності електоральним стандартам та загальносвітовим демократичним принципам.

Аналіз актуальних досліджень. Розпочинаючи аналіз еволюції та трансформації виборчих процесів української держави, слід відзначити фахову та плідну науково-дослідницьку роботу низки експертів суспільногуманітарного дискурсу серед яких, зокрема, Т. Авксентьєва, С. Гелей, Л. Герасіна, І. Дробінка, В. Журавський, Ф. Кирилюк, А. Коваленко, Т. Кришталь, М. Обушний, М. Панов, Ю. Підгорецький, В. Піча, Б. Старушін, Л. Тіхонова, О. Ткач, Н. Хома, Н. Чорна, В. Штанько та інші.

Окремо слід відзначити грунтовні дослідження таких науковців як О. Головко, В. Гончаренко, В. Горленко, Г. Еллинек, В. Срмолаєв, М. Киян, О. Марченко, О. Мельничук, М. Наход, Т. Плаксій, М. Рибачук, В. Токарев, Л. Шара, І. Шкурат, Т. Щерба, А. Югов, та інші (Чепіль та Докаш, 2015, с. 635), що присвячені питанням формування, функціонування та модернізації виборчої системи України.

Проблематика «інституту виборів» та трансформацій виборчого процесу представлена широким спектром наукових розвідок західних дослідників, серед яких - Г. Алмонд, Т. Браун, С. Верба, Л. Даймонд, Г. О. Доннел, Т. Карл, Т. Кіс, Д. Ламберт, Е. Лейкман, Д. Мілль, Р. Таагепер, М. Уорелстайн, Ф. Фукуяма Т. Хейрам, Ф. Шміттер, М. Шугарт.

Питання становлення та трансформації виборчих процесів належать до пріоритетних напрямів сучасної науково-дослідницької роботи, відтак перебуває у фокусі уваги провідних українських вчених. На підтвердження даної тези наведемо декілька цитат: так, О. Галус «інститут виборів» тлумачить як «сукупність правових норм, які регулюють суспільні відносини, що виникають при здійсненні безпосереднього народовладдя у формі виборів» (Дейдей, 2018, с. 112); М. Киян (2013, с. 402) справедливо зазначає 
про неможливість сучасного політичного життя українського суспільства без виборів. На думку вченого, для осягнення суті сучасного українського виборчого процесу існує необхідність дослідження історії виборчого процесу, адже кожен етап розвитку суспільства вирізняється виборами та виборчим правом із різними характеристиками, які «згодом позначаються на розвитку виборчого та державного права в цілому»; М. Рибачук та I. Шкурат (2004, с. 94-95) визначають «виборчу систему, як сукупність правил, прийомів і процесів, що забезпечують і регулюють легітимне формування державних представницьких органів політичної влади». В основі виборчої системи кожної окремої країни - законодавство, що має деталізувати їі основні положення, зафіксовані в Конституції країни.

У виборчому законодавстві приділяється значна увага виборчому процесу, тобто певній врегульованій правовими нормами сукупності дій громадян і уповноважених органів, які спрямовані на формування якісного і кількісного складу органів державної влади та органів місцевого самоврядування. Науковці-державознавці поки що не виробили консолідованої позиції щодо поняття виборчого процесу, зокрема, I. Ільінський, Б. Страшун, В. Ястребов визначають виборчий процес як діяльність уповноважених суб єктів 3 підготовки і проведення виборів, а також норми, що таку діяльність регулюють (Стешенко, 2013, с. 108). А в дослідницькій аргументації вчених В. Молдован та В. Мелащенко, це встановлена законодавством процедура, порядок організації і проведення виборів, один із елементів виборчої системи (Стешенко, 2013, с. 108). В українській юридичній енциклопедії виборчий процес теж сформульовано як один з основних елементів виборчої системи, що забезпечує організацію проведення виборів у встановленому законом порядку (Стешенко, 2013, с. 108). Наголосимо, подібні «різночитання» поняття «виборчого процесу» вказують на його складність у теоретико-методологічному визначені та обумовлюють потребу в подальших науково-дослідницьких проектах, щодо означеної проблематики, зокрема дослідження еволюції виборчого процесу. 
Мета статті - дослідити еволюцію та трансформацію законодавчого забезпечення виборчого процесу в українському суспільстві.

Виклад основного матеріалу. Дослідження започаткування виборчих практик на теренах української держави слід розпочати 3 визначення хронологічних координат та засадничих принципів народного волевиявлення.

Через брак джерел, дослідження історичного розвитку інституту виборів в Україні постає досить складним завданням. Вчені припускають наявність даного інституту на різних рівнях суспільно-політичного життя народів, які ще з давніх часів мешкали на території сучасної України, або ж із часом прийшли на неї чи стали опосередкованим чинником, що вплинув на розвиток політичного організму. Прикладом початків розвитку державності в межах сучасної України вважається Скіфське царство (Правова сторінка, 2012). Так, інформацію щодо племен, які займали дану територію, можна побачити у Геродота (V століття до н. е.). Дане джерело акцентує увагу на наявність могутнього племінного союзу у скіфів, жителів території сучасної України, що населяли їі у VII столітті. Досить високому ступеню розвитку скіфів відповідала організація управління - військова демократія. В межах такої демократії існували так звані збори воїнів, на яких розглядалися найважливіші питання, серед впливових структур також можна назвати ради родових старійшин, союзну раду. Особлива роль в них належала військовим вождям («царям»), що очолювали військо під час походів. Не дивлячись на те, що їх влада була спадковою, вона мала бути затверджена народними зборами (Рибачук та Шкурат, 2004, с. 83). Перші спроби народного волевиявлення, що мали місце в суспільно-політичній культурі Скіфського царства, обгрунтовано визнаються науковцями як підгрунтя для становлення демократичної традиції української держави.

Хронологічний ряд становлення та розвитку «виборчих практик» продовжує Віче - народні збори як інструмент впливу народу на державну політику. Як зазначає М. Грушевський (1992, с. 103), основою для віче були 
племінні сходи давніх слов’ян, які в подальшому перетворилися на зібрання за участю вільних жителів міста (купців, ремісників та ін.). В той же час вчений наголошує на вирішальній ролі у цих зборах міської феодальної верхівки - «бояр» та «старців графських». Серед важливих функцій віча комплектування народних ополчень і обрання їх ватажків. Відповідно, воно скликалося під час облоги міста, перед початком воєнних походів, на знак протесту проти політики князя. Виконавчий орган віча - рада, яка могла не тільки репрезентувати його, а й заміняти (через те, що віче збиралося рідко) (Грушевський М., 1992, с. 103). Згодом замість віча князь починає збирати раду наближених феодалів, землевласників, духовенства - бояр. Із зміцненням влади князів і державного апарату діяльність віча відмирає. Виняток становили лише віча у Пскові та Новгороді.

Дескрипція становлення та трансформації фундаментальних виборчих принципів української держави потребує звернення до аналізу демократичного устрою Запорізької Січі та унікального суспільнополітичного, військово-адміністративного, культурно-історичного явища в царині світової демократій - козацтва, для якого були властиві виборчі засади від самого його виникнення. У козаків Запорізької Січі верховною законодавчою владою була січова рада. Протягом певного періоду в козацькій державі склалися традиції самоврядування, відповідно до яких усі iii члени мали рівні права і могли брати участь у козацьких радах» (Osvita.ua, 2011).

Iз підписанням Богданом Хмельницьким Зборівського договору у серпні 1649 р. на території Київського, Брацлавського та Чернігівського воєводств утворилася автономна Українська держава. Своєрідним законодавчим органом в ній постала Старшинська рада, постанови якої були обов’язковими i для гетьман, але через те, що вона була установою підвладної держави, коло пї повноважень було обмеженим, і чимало питань верховного управління вирішувалося поза нею. Iз утворенням Малоросійської колегії в уряді царської Росії у 1764 р. існування Ради 
припинилося. Таким чином, ми бачимо, що у кінці XVII ст. через зміцнення російської присутності в Україні відбувається послідовне обмеження виборів місцевих органів влади (Климкова та Остапенко, 2011, с. 45).

Наступною віхою в розвитку української демократії стає Конституція Пилипа Орлика (1710р.) - унікальна пам’ятка політико-філософської та правової думки, яка визначила подальшу трансформацію виборчих практик та затвердження ліберально-демократичних традицій в Україні. Так, науковці М. Киян та М. Окладна (2010, с. 1) звертають увагу на особливу роль Конституції П. Орлика у формуванні конституційних ідей в Україні. Від часів Переяславської ради провідною стає вимога автономії України, яка в XIX ст., доповнюється ідеями переустрою суспільства на загальнолюдських засадах демократії й справедливості. У саме у такому руслі ідея незалежності України була втілена в конституційних проектах «Начерки Конституції республіки» (автор - один 3 членів Кирило-Мефодіївського братства Г. Андрузький), та проекту Конституції України під назвою «Вольний союз» (Вільна спілка) М. Драгоманова (Киян та Окладна, 2010, с. 1).

При дослідженні еволюції та трансформації вітчизняних виборчих практик важливо зробити наголос на специфіці української історії, а саме, - iї перебування тривалий час під впливом іноземних імперій, зокрема, АвстроУгорщини, Росії, що суттєво позначилось на традиціях українського народного волевиявлення. Так, провідні українські науковці С. Обрусна та М. Ільницький $(2017$, с. 62) в роботі «Становлення виборчої системи для проведення виборів народних депутатів України: історико-правовий аспект» вказують на вплив у формуванні вітчизняної виборчої традиції іноземних держав, до складу яких у той чи інший період входила Україна. Автори звертають увагу на входження більшої частини українських земель на початку XIX ст. до складу Російської імперії, а іншої частини до складу Австро-Угорської імперії i, відповідно, на їх вплив у розвитку як виборчих традицій, так і політичної культури та електоральних настроїв. Дослідники вказують на наявність виборчої системи Російської імперії у пї більш 
сучасному розумінні з часу проведення земської реформи - 31864 p. Не дивлячись на надання переваги дворянському представництву у земствах, в даній системі вже можна відслідкувати такі поняття як «квота», «цензи». Прикладом виборчої інституції російського політичного устрою вчені також називають міську думу, яка вважалася розпорядчим органом міського самоврядування, що складався із представників різних суспільних верст. Науковці також уточнюють значущість даного органу для подальшого розвитку виборчої культури, не дивлячись на ситуацію, що склалася після реформи 1870 р., коли обрання до думи здійснювалося на засадах майнового цензу Із прийняттям у 1870 р. «Міського положення» в українських містах встановлювалась виборча система та система міського самоврядування. В цьому документі закріплювався принцип надання виборчих прав усім мешканцям міста без врахування їх майнового стану та соціального походження. Але принцип рівності участі у виборах нівелювався тим фактом, що у роз'ясненнях до положення зазначалося про врахування не особистої зацікавленості при наданні мандату депутату думи, а майнової зацікавленості в облаштуванні міста, тобто більше шансів мала особа із високим майновим становищем (Обрусна та Ільницький, 2017, с.62).

Звертаючи увагу на аналіз інституту виборів та виборчих систем у історичні періоди панування Австрії та Польщі на території України, необхідно відмітити, що відповідно до декрету австрійського імператора від 1861 р., Галичина, як одна 3 австрійських провінцій, мала право обирати свій крайовий законодавчий орган місцевого самоврядування - Галицький сейм. Він являв собою представницький орган, що складався із курій, до яких обирали депутатів від кожної верстви населення окремо. Так, у першу курію входили великі землевласники, поміщики, священики $(0,03 \%$ від усього населення, та третина депутатських місць), митрополити, єпископи та ректори університетів. Представники другої курії - заможна міська буржуазія, адвокати, лікарі тощо. Третя - представляла торгово-промислову буржуазію. Четверта, сільська курія - платників податків (селян). Відповідно, 
ті, хто не сплачував податки - сільська біднота, міські робітники, не мали виборчого права. Саме тому не можна казати однозначно про загальне і рівне виборче право у ці часи. Як зазначають дослідники виборчого права, лише у 1907 р. у Австрії запроваджується загальне виборче право, при цьому жінки, військовослужбовці та молодь до 24 років не мали права обирати. До того ж воно використовувалося в інтересах німецьких правлячих кіл. Так, вчені наводять наступні дані: «німці обирали одного депутата від 40 тисяч населення, поляки - від 52 тисяч, чехи - від 60 тисяч, а українці - від 102 тисяч» (Рибачук та Шкурат, 2004, с. 87). В подальшому, змінам у виборному законодавстві Австрії сприяла боротьба галичан проти несправедливої виборчої системи, заснованої на майновому цензі.

Вже за часів Західноукраїнської Народної Республіки Українською національною радою було прийнято новий виборчий закон у квітні 1919 р., де позиціонувалася національно-пропорційна система у виборах до однопалатного Сейму. Така система передбачала, що за кожною національністю, в залежності від кількості населення, визначається певне число послів. Це стало гарантією для національних меншин, в незалежності від обставин, мати у парламенті своїх представників. Це стало прогресом у розвитку демократичного забезпечення прав національних меншин при виборах законодавчих органів (Климкова та Остапенко, 2011, с. 48-49).

Початок $\mathrm{XX}$ століття позначився фундаментальними змінами $\mathrm{y}$ демократичній перебудові української держави - затвердження Центральної Ради, проголошення Універсалів, обрання М. Грушевського Президентом УНР та схвалення Конституції Української Народної Республіки ознаменували новий етап в традиції народного волевиявлення, 3 беззаперечною орієнтацією на загальносвітові демократичні принципи.

Дослідники підкреслюють, що у виборах, які проводилися за час перебування Західної України під Польщею (1919 - 1939 рр.) до польського сейму (1922, 1928, 1930 роки) акцент здійснювався не на безпосередньо висуванні населенням своїх представників, а на прагненні влади домогтися 
визнання українцями факту державної приналежності до Польщі через їх участь у виборах (Киян та Окладна, 2013, с. 10). XX століття представило інституцію суспільного представництва - Українську Центральну Раду (засновано 3 березня 1917 р. у Києві). Своїм III Універсалом Центральна Рада проголосила про утворення Української Народної Республіки (УНР), ухвалила рішення щодо виборів Українських Установчих зборів, та у квітні обрала Президентом проголошеної республіки М. Грушевського а також схвалила Конституцію УНР, яка вважається фактично першою конституцією України, в якій було враховано один з принципів західної демократії - поділ влади. Функцію законодавчої влади здійснювали Всенародні Збори, що мали обиратися через всенародне голосування (Киян та Окладна, 2013, с. 10).

Історичний період перебування України у складі СРСР не сприяв демократизації виборчих процесів та виборчого законодавства і на тривалий час призупинив розвиток реального народовладдя. Проте, були й певні позитивні аспекти. Так, сучасна Верховна Рада веде родовід від Верховної Ради УРСР, яка за назвою, структурою, кількістю депутатів і за основними принципами виборчого права була близькою до парламенту сучасної України. А провідний вітчизняний експерт з історії виборчого законодавства М. Ставнійчук (2001) наголошує, що «із 1936 до 1977, 1978 років загальне правове регулювання вищих представницьких органів України здійснювалось на основі Конституції СРСР, Конституції УРСР і підзаконних актів - «Положення про вибори до Верховної Ради УРСР» від 21.02.1938 р., від 26.10.1946 р., від 12.12.1950 р.; після - Конституцією СРСР 1977 року. І Конституцією УРСР 1978 року Законом «Про вибори до Верховної Ради Української РСР» від 19.12.1978 р. У період 1985-1990рр. здійснювалось реформування виборчого законодавства на території СРСР і в т. ч. УРСР» (Ставнійчук, 2001).

Завдяки національно-демократичним силам та активній громадянській позиції рядових українців в 1991 році було розпочато масштабний проект новітнього державотворення України. Так, О. Галус (2013, с. 37) зазначає, що 
«час від здобуття Україною незалежності і до прийняття Конституції України 1996 р.» постає як окремий етап в історії становлення інституту виборів незалежної України, адже «в Основному Законі вперше народ було визнано носієм суверенітету й єдиним джерелом влади, а на розвиток цього конституційного положення у ст. 69 Конституції було закріплено, що народне волевиявлення здійснюється через вибори, референдуми та інші форми безпосереднього народовладдя» .

Підкреслимо, типовою рисою українських виборів $є$ часті зміни у виборчому законодавстві: «За добу Незалежності в Україні було проведено вісім парламентських кампаній за різними виборчими системами. Якщо окреслювати концептуально, то застосовувалися усі три базові виборчі системи: мажоритарна, пропорційна i змішана. У хронологічній послідовності це відображається таким чином: 1994 рік (мажоритарна система абсолютної більшості), 1998 і 2002 роки (змішана за принципом 50/50), 2006 і 2007 роки (пропорційна), 2012 і 2014 роки (повернення до змішаної за принципом 50/50)» (Яковлєва, 2018, с. 78). У 2019 році продовжує діяти змішана виборча система: 225 народних депутатів обрано за партійними списками та 199 - на одномандатних округах (26 округів розташовані на окупованій Російською Федерацією території, там вибори не відбувалися). Кожний виборець отримав два бюлетені: один із переліком партій, другий - зі списком «мажоритарників».

У вітчизняному експертному середовищі досі не виробили узгодженої позиції щодо питання оптимального типу виборчої системи, триває складний процес пошуку засобів оптимізації норм виборчого законодавства та наближення їх до загальновизнаних міжнародних виборчих стандартів. У зв'язку із виборчою боротьбою на пост президента України та виборами народних депутатів України, що відбулися у 2019 р., актуальним сьогодні залишається питання формування виборчого процесу в Україні. Особливої уваги потребує виборча система при проведенні виборів народних депутатів та депутатів і посадових осіб органів місцевого самоврядування. Адже 
ефективність та дієвість виборчої системи на виборах народних депутатів України значною мірою впливає на якість механізмів формування парламентської більшості, уряду, інших органів державної влади.

Висновки і перспективи подальших досліджень. Виборчий процес $є$ визначальним щодо майбутнього політичного життя кожної країни, а саме виборча система та виборче законодавство $є$ важливими показниками народовладдя і мають суттєве значення для становлення України як правової та демократичної держави. Історичний досвід і сучасна практика вказує на те, що парламентаризм на сьогоднішній день $є$ найбільш ефективною моделлю політичної організації суспільства. Однак рівень формування українських представницьких установ залишається ще далеким від досконалості, наприклад, ще не завершена політична реформа в Україні, не достатньо ефективною $\epsilon$ робота Верховної Ради, далекими від оптимальних залишаються ii відносини із управлінськими структурами, силовими структурами, багато нарікань викликає виборча система. Аналіз розвитку виборчої системи та виборчого законодавства від періоду Давньої історії до сьогодення дає підстави стверджувати, що існує тенденція до деталізації та розширення обсягу норм, які регламентують порядок здійснення виборчих процедур. Але якою б не була виборча система в Україні, чи пропорційна, чи мажоритарна, чи змішана, головне, щоб виборче законодавство було стабільним та захищеним від маніпуляцій. Для цього необхідно на законодавчому рівні заборонити приймати зміни до відповідних нормативноправових актів за рік до виборів. Доцільним є ухвалення Виборчого кодексу України, який охоплював би весь спектр виборчого законодавства, запровадивши складну процедуру внесення змін до нього, унеможлививши маніпулювання виборчими нормами в інтересах певних політичних сил.

Додамо, вкрай важливо усвідомити, трансформації потребує не лише виборче законодавство, а й політична культура всіх суб'єктів виборчого процесу, для сучасних українців, що сповідують загальносвітові ліберальнодемократичні принципи, ціннісно-нормативним імперативом повинна стати 
наступна теза: головна функція «виборів» - цуе консолідаџія громадян задля корегування поточної політики в державі.

\section{ЛІТЕРАТУРА}

1. Галус, О.О., 2013. Становлення та розвиток інституту виборів в Україні. Університетські наукові записки, 4, с. 36-41.

2. Готун, А. М., 2008. Використання нових інформаційних технологій у виборчому процесі: світовий досвід і практика застосування в Україні. Вісник КНУ імені Тараса Шевченка. Філософія. Політологія, 89-90, с. 51-55.

3. Грушевський, М. 1992. Ілюстрована історія Украӥни. Київ: Наукова думка.

4. Дейдей, М., 2018. Еволюція виборчого законодавства як основи формування представницької влади на місцевому рівні. Інвестиції: практика та досвід, 24, с. $110-114$.

5. Киян, М. Ш. та Окладна, М. Г., 2013. Деякі історичні аспекти формування виборчих технологій в українських землях. Громадянське суспільство, 69, с. 8-13.

6. Киян, М. Ш. та Окладна, М. Г., 2010. Незалежна Україна: від автономії до суверенітету. Збірник наукових праць "Вісник НТУ "ХПІ": Актуальні проблеми розвитку українського суспільства, 35, с. 1-4.

7. Киян, М. Ш., 2013. Історичний досвід становлення виборчих технологій в українських землях у XVIII столітті. Форум права, 1, с.402-407 [online]. - Доступно: http://archive.nbuv.gov.ua/e-journals/FP/2013- 1/13kmsuuc.pdf [Дата звернення 19 Серпень 2019]

8. Климкова, I. І. та Остапенко, М. А., 2011. Вибори і виборчі системи: навч. посіб. для студ. вищ. навч. закл.. Київ: ДП «Видавничий дім «Персонал».

9. Кормич, А. І. та Кормич, Л. І., 2013. Специфіка виборчого процесу та особливості формування електорального простору сучасної України. Актуальні проблеми політики, [online] 48, c. 28.2 Доступно: http://dspace.onua.edu.ua/bitstream/handle/11300/2153/Kormich_A.pdf?sequence=1\&isAl lowed=y [Дата звернення 14 Серпень 2019]

10. Наход, М. А., 2011. Проблеми становлення та реформування виборчої системи для проведення виборів народних депутатів України. Демократичне врядування, [online] 7. Доступно: http://nbuv.gov.ua/UJRN/DeVr_2011_7_10 [Дата звернення 17 Серпень 2019]

11. Обрусна, С. Ю. та Ільницький, М. С., 2017. Становлення виборчої системи для проведення виборів народних депутатів України: історико-правовий аспект. Науковий вісник Херсонського державного університету, 3 (1), с. 61-66.

12. Рибачук, М. та Шкурат, I., 2004. Історичні аспекти становлення виборчої системи України. Політичний менеджмент, 1, с.83-98.

13. Сайт Солом'янської районної державної адміністрації в місті Києві, 2012. Правова сторінка. Виборча система. [online] (Останнє оновлення 18 Вересень 2012) Доступно: http://www.solor.gov.ua/info/19/4619 [Дата звернення 20 Серпень 2019]

14. Ставнійчук, М. I., 2001. Законодавство про вибори народних депутатів Украйни: актуальні проблеми теорії і практики ред. В. Ф. Погорілко; Інститут держави і права ім. В.М. Корецького НАН України. Київ: Факт. 
15. Стешенко, Т. В., 2016. Сучасні тенденції розвитку виборчого законодавства України. Visegrad journal on human rights, 2(1), c. 130-134

16. Стешенко, Т. В., 2013. Актуальні питання виборчого процесу в Україні і зарубіжних країнах. Державне будівниитво та місиеве самоврядування, 25, с. 102-113

17. Чепіль, Л. Ю. та Докаш, О. Ю., 2015. Історичні передумови становлення виборчої системи в Україні. Наукова Україна. Збірник матеріалів Всеукраїнської студентської наукової конференції з міжнародною участю 25 травня 2015 р. Дніпропетровськ: «SeKum Software», [online] c. $791 . \quad$ Доступно: file://C:/Users/ASUS/Desktop/Zbirnik_Naukova_Ukrayina_copy.pdf [Дата звернення 11 Серпень 2019]

18. Яковлєва, Н., 2018. Динаміка змін системи виборів народних депутатів України. Ukrainian Politconsulting Group. [online]. - Доступно: http://upgroup.org.ua/dinamikazmin-sistemi-viboriv-narodnih-deputativ-ukrayini/\#more-2828 [Дата звернення 20 Серпень 2019].

19. Osvita.ua., 2011. [online] Становлення виборчої системи в Украӥні: історичні аспекти. Доступно: https://osvita.ua/vnz/reports/politolog/17354/ [Дата звернення 12 Серпень 2019].

\section{Інформація про автора}

Нечасва Ганна Миколаївна - аспірантка кафедри політології, соціології і культурології Харківського національного педагогічного університету імені Г.С. Сковороди; e-mail pekines1@gmail.com; ORCID: http://orcid.org/0000-0002-3240-3555.

Стаття надійшла до редакції: 17.10.2019 р. $\quad$ Прийнята до друку: 04.11.2019 p. 